\title{
CORRIGENDUM
}

\section{Early unpredictability predicts increased adolescent externalizing behaviors and substance use: A life history perspective-CORRIGENDUM}

\author{
JENALEE R. DOOM, ADRIENNE A. VANZOMEREN-DOHM, AND JEFFRY A. SIMPSON \\ University of Minnesota Institute of Child Development
}

doi:10.1017/S0954579415001169, published by Cambridge University Press, 9 December 2015

The affiliation for all authors should have been the University of Minnesota only, and the correspondence address was incomplete: Jenalee R. Doom, Institute of Child Development,

\section{Reference}

Doom, J. R., Vanzomeren-Dohm, A., \& Simpson, J. A. (2015). Early unpredictability predicts increased adolescent externalizing behaviors and sub-
University of Minnesota, 51 East River Road, Minneapolis, MN 55455; E-mail: doomx008@umn.edu. We regret these errors and any problems they may have caused.

stance use: A life history perspective. Development and Psychopathology. Advance online publication. doi:10.1017/S0954579415001169 